\title{
Revival of Aggregate Demand Policies - Introduction
}

\author{
Roel Beetsma* and Gerhard Illing**
}

This issue contains a selection of the papers presented at the workshop "The Revival of Aggregate Demand Policies: Back to Keynes" that took place in Venice in July 2004. During recent years, there has been growing consensus that monetary policy can work as an effective stabilisation mechanism. Using formal (dynamic) general equilibrium models based on micro-foundations, the so-called New Keynesian approach - the workhorse of modern macroeconomics - provides sophisticated tools for exploring the implications of monetary policy. Whereas the academic literature, until recently, focused mainly on monetary policy, it is now paying increasing attention to the fiscal side of aggregate demand management. This conference issue aims to provide a critical appraisal and extension of that literature, focusing both on fiscal and monetary aspects.

Recently, fiscal policy has become popular again among policymakers as a stabilisation tool. Tax cuts in the U.S. have been partly motivated by the argument that they would stimulate the economy by increasing demand. Similarly, the protracted sluggishness of the German and French economies has led to tax reductions. Given that in the Euro Area monetary policy no longer responds to national shocks, many call for a stronger role of fiscal policy as a stabilisation tool. Not so long ago the French President Chirac and the German Chancellor Gerhard Schröder jointly called for setting up large infrastructural projects to revive the European economy. While such projects affect the supply-side in the longer run by boosting European productive capacity, the short-run effect would be an increase in employment, hence income and spending, and thus a boost to aggregate demand.

For a long time, academic researchers have been sceptical about aggregate fiscal demand management on the ground that fiscal fine-tuning is impossible due to decision and implementation lags, as well as uncertainty about the way the economy works. But their interest in the effects of fiscal policy impulses has recently been revived. Samples of recent contributions are Burnside et al. (2003), who look at the effects of major shocks to military spending in the U.S., Blanchard and Perotti (2002), who use detailed institutional information

\footnotetext{
* Department of Economics, University of Amsterdam, Roetersstraat 11, 1018 WB Amsterdam, e-mail:R.M.W.J.Beetsma@uva.nl.

** Department of Economics, University of Munich, Ludwigstraße 28, 80539 Munich, e-mail: illing@Imu.de.
} 
on tax elasticities and tax collection lags to identify discretionary fiscal policy changes, and Perotti (2005), who tackles the same issue in an empirical analysis for major OECD economies. Other recent contributions in this area are Fatas and Mihov (2001), Canova and Pappa (2002), Marcellino (2002), Mountfort and Uhlig (2002) and Favero (2003). Giuliodori and Beetsma (2004) extend the issue into another direction and look at the cross-border trade spill-over effects of a fiscal stimulus in large European economies.

At this juncture it becomes important to explain what we mean by aggregate demand management. As far as monetary policy is concerned, many researchers assume that it is conducted by some rule, usually one in which the shortrun interest rate (the monetary authority's instrument) is linked to inflation or expected future inflation and some measure of economic activity (as in the well-known "Taylor rule"). Deviations from this rule are often interpreted as discretionary monetary policy changes. For fiscal policy, matters are more complicated. Fiscal policy (taxes and spending) is to a large extent automatically determined by movements in economic activity (a boom raises revenues and reduces spending on, for instance, unemployment) and servicing costs of public debt (especially for high-debt countries). On top of that, the authorities may follow some rule in which they systematically link revenues and spending to, for example, movements in public debt (an increase in debt might be met with an increase in the primary surplus). ${ }^{1}$ Deviations of taxes and spending from the values determined by automatic responses in activity and systematic policy responses to economic developments would qualify as discretionary fiscal policy changes. Examples of discretionary fiscal policy changes are increases in U.S. defence spending to finance the Iraq invasion or the recent additional spending cuts introduced by the Dutch government as a result of an unforeseen budgetary deterioration. The papers in this issue analyse to what extent systematic rules and/or discretionary policy responses can or should be designed as tools for aggregate demand management.

While the New Keynesian approach has mainly been used to explore the implications of monetary policy, attempts are now also being made at introducing fiscal policy into the framework. ${ }^{2}$ Torben Andersen discusses the need and scope for active fiscal stabilization policy in that context. A number of factors determine the answer to these questions. First, it is crucial whether activity is supply-determined or demand-determined. Under a demanddetermined activity level lower than the capacity level, an increase in public consumption raises activity in the short run. In fact, as Andersen points out, it is important to realise that the short-run effect of a fiscal expansion may differ

1 Ballabriga and Martinez-Mongay (2003) estimate fiscal rules of this type.

2 For instance, see Beetsma and Jensen (2004; 2005) and Lombardo and Sutherland (2004). 
substantially from the long-run effect. Even if the latter is negative, there could still be a case for a fiscal stimulus, as long as it is temporary.

Another factor to be taken into account is the instrument that might be most effective in stimulating activity. When Ricardian equivalence holds, changes in taxes have no effect, while an increase in public consumption stimulates activity, although at the cost of some crowding out of private consumption. Only if the spending stimulus is short-lived, then the crowding-out effect is small. In contrast, in the presence of liquidity constraints, a tax reduction boosts output by raising disposable income for those who are constrained. An additional decisive factor is the role of expectations, much like in the case of monetary policy. For example, a temporary policy measure which is actually perceived as permanent, will largely lose its effectiveness, because the private sector increases its saving in anticipation of the substantially higher future taxes. Fiscal contractions may lead to expectations of a reduction of the size of the public sector and, therefore, could have an expansive effect on the economy (for example, Giavazzi and Pagano 1990).

Information requirements, as well as the potential for political abuse, cause Andersen to be sceptical about the desirability of active fiscal stabilisation policy. He argues that proposals to delegate stabilisation policy to independent institutions (such as a "fiscal board") will run into serious difficulties since it might be inefficient to separate stabilisation, allocation and distribution. Automatic stabilisers do not suffer from these weaknesses. Even under a balanced budget they may enhance welfare by spreading risks over private and public consumption. They become even more effective when the balanced budget requirement is relaxed. This would allow smoothing of consumption over time, something that might be hard to achieve through private markets. Unfortunately, automatic stabilisers have disadvantages, too. They do not distinguish between the sources of shocks, neither can they distinguish permanent from temporary shocks. For example, a permanent or very persistent adverse shock (such as in the seventies) could lead to systematic, unsustainable budget movements that can only be offset with a discretionary fiscal change.

Anton Muscatelli and Patrizio Tirelli (2005) examine the empirical effects of fiscal policy in New-Keynesian models. They show that introducing additional features can improve the empirical performance of the models. They allow for habit persistence in consumption, a fraction of rule-of-thumb consumers, price stickiness, a share of firms that index their prices to inflation, government expenditures, and taxation effects on consumption and firms' marginal costs. The models they consider are a single-country model with infinitely-lived consumers (hence Ricardian equivalence holds), a singlecountry model with finitely-lived consumers, so that Ricardian equivalence breaks down and public debt affects economic allocations and, finally, a two- 
country model of a monetary union. The models feature simple monetary and fiscal rules. Monetary policy follows an inertial Taylor-like rule in which the interest rate responds to expected future inflation and output gaps. Fiscal policy follows backward-looking rules, linking government consumption and taxes to their own lagged values and the past output gap. The two-country version of the model also assumes that spending and taxes are linked to public debt, which could represent the presence of a fiscal restriction like Europe's Stability and Growth Pact. These fiscal rules might be interpreted as combining an automatic stabilizer component (in particular, as far as the link with the output gap is concerned) with a discretionary component. The model parameters are partly calibrated and partly based on estimates from previous studies.

For both demand and supply shocks the authors simulate different versions of the models to examine the transmission of fiscal policy. First, they study the single country models. Complementing the monetary rule with the fiscal rule only has a minor additional stabilising effect. An increase in the number of rule-of-thumb consumers, even though it improves the scope for fiscal policy, reduces the degree of stabilisation. This is due to the fact that monetary policy becomes less potent because the impact of an interest rate change on aggregate demand diminishes (as the consumption of the rule-of-thumbers is insensitive to the interest rate). Assuming finite rather than infinite lives makes fiscal policy more powerful, as Ricardian equivalence is broken. However, while initial stabilisation is larger, adjustment towards the steady state is no longer monotonic, but takes place in cycles. Translating the results into unconditional standard deviations for inflation and output, it is found that, in the case of supply shocks, adding fiscal policy reduces output volatility at the cost of increased inflation volatility. Hence, fiscal policy reveals the same trade off that monetary policy faces in the presence of supply shocks. Not surprisingly, given the higher steady-state share of taxation, the impact of fiscal policy in Europe is larger than in the U.S.

Simulations for the two-country monetary union show that fiscal policy in the presence of a unilateral positive demand shock becomes less potent. The reason is that the ensuing monetary contraction by the common central bank pushes the other economy into recession. This country will therefore expand its fiscal policy, thereby offsetting part of the contractive effect of the fiscal policy in the shock-hit economy.

In his paper, Jordi Galí surveys his recent research on two central themes of Keynesian economics, namely the social waste associated with recessions and the effectiveness of fiscal policy as a stabilization tool. The availability of formal (dynamic) modelling methods based on micro-foundations, as employed by real business cycle theorists, has reinvigorated the analysis of the consequences of price and wage rigidities. While RBC theorists view business 
cycles are the result of the economy's optimal response to shocks, the Keynesian view is that these cycles are associated with variations in the efficiency with which productive resources are used. Recessions are thus periods of increased waste of such resources, so that public policy can play a useful role.

One of the features of (many) New-Keynesian economics is that the output gap should be defined as the difference between actual output and the efficient output level that prevails under fully flexible wages and prices. Galí splits this gap into a component that captures inefficiencies in product markets (due to imperfect competition) and another one that arises from distortions in the labour market (such as non-competitive wage-setting and distortionary taxes on labour). A plot of this gap computed for postwar US data reveals two key features. The gap, as defined by Galí, is substantially more volatile than conventional output gap measures based on a (relatively) smooth trend. The other feature is that both Gali's and the traditional measure are highly correlated, indicating that recessions are indeed periods of increased inefficiency in the economy. Further, empirical evidence suggests that variations in the labour market wedge are the dominant source of fluctuations in the output gap.

If inefficiencies drive the output gap, in principle there is a case for policies that stimulate aggregate demand. One needs to be careful in distinguishing policies that reduce fluctuations around the steady state and policies that aim at limiting recessions. While the former lead to only second-order welfare gains, the latter lead to first-order welfare gains, given that the steady state is distorted (e.g. because of monopolistic competition). Galí goes on to present a simple model in which individuals care about private and public goods consumption, as well as leisure. He derives the optimal level of public purchases and shows that they can be used to increase employment, thereby reducing the welfare losses caused by an inefficiently low level of economic activity. Moreover, the incentive to increase government spending becomes stronger the larger is the output gap.

The final line of work discussed in Gali's paper looks at the role that discretionary fiscal policy might have had in the decline in GDP volatility over the past decades. Martin and Rowthorn (see below) document this decline in detail and mainly attribute it to better monetary policies. However, the substantial increase in the counter-cyclicality of fiscal policy claimed by Galí and Perotti (2003) suggests that this may have been a contributing factor too.

The paper by Robert Woods considers the implications for the stabilisation of the British economy if Britain were to join the European Monetary Union (EMU). Obviously, there would be less stabilization through monetary policy, since the latter would be linked to average developments in the Euro area. The burden on fiscal stabilisation policies would become correspondingly larger. 
Woods describes a proposal by HM Treasury (2003) for a fiscal stabilisation rule in which a discretionary fiscal reaction would be triggered when the output gap was expected to exceed a certain threshold in either direction away from the zero level (the suggested threshold was $+/-1.5$ percent). Such a rule has certain advantages above a rule in which fiscal policy continuously reacts to movements in the output gap. This is in particular the case when there are fixed costs for the private sector of adapting to changes in fiscal policy (such as a change in the VAT rate). Further, given the uncertainty about the size of the output gap, it may be better to only take action when developments appear to become rather extreme, which minimizes the risk of implementing a procyclical fiscal policy. Finally, employing a trigger rule rather than a continuous rule would send a signal that the rule is not meant for fine-tuning, but rather to counteract persistent cyclical fluctuations. Obviously, with the trigger based on expected rather than actual output gap movements, many unexpected shocks would be missed. However, the risk of pro-cyclical discretionary fiscal policy actions would also be minimized and only the more persistent (and, arguably, more relevant) shocks will lead to discretionary action.

The criteria for a proper discretionary fiscal policy are that the policy is transparent and credible, and that it operates in a symmetric and timely manner. The latter two objectives are, in principle achieved by acting in response to expected output gap movements and by setting symmetric thresholds around a zero gap level. Of course, persistent over- or underestimation of the potential output level, as allegedly has happened in the seventies, could still lead to a de facto asymmetrically operating rule. The transparency requirement can be more easily met if the trigger is based on a single number. Of course, transparency also requires clarity about the specific actions that the government is going to take when the thresholds are exceeded. As far as the choice of the fiscal instrument is concerned, Woods expresses a preference for temporary changes in expenditure taxes. Empirical studies have shown that such changes can have profound effects on aggregate demand, although the effects tend to be rather short-lived and concentrated closer to the date when the changes are actually implemented rather than when they are announced.

Over the past decade, major industrialised economies have enjoyed low economic volatility. After providing summary statistics, Bill Martin and Robert Rowthorn (2005) try to explain what has caused the reduction in fluctuations in output growth and inflation. A better understanding of the sources of enhanced stability could inform us about how stability can be prolonged if it has been the result of improved economic policies and the likelihood that it will last if it is caused by a reduction in the size of exogenous economic shocks.

Potential explanations of increased stability fall into three main categories: structural economic changes that promote stability, improved economic poli- 
cies and a reduction in the exogenous shocks hitting the economies. Martin and Rowthorn reject all explanations that fall into the first category - a shift from manufacturing to services, better inventory management and financial market deregulation allowing for better consumption smoothing. Given that the rise and fall of output volatility coincides with changes in inflation volatility, attention then turns to changes in the behaviour of inflation and the underlying policies. The data suggest that both inflation persistence and the response of inflation to output (the slope of the Phillips curve) have fallen in the past two decades. A source of such changes may be the increased credibility of inflation targets and central banks, leading to lower inflation expectations and less passthough of costs and past inflation movements into current price rises. As the authors show, enhanced credibility of monetary policy can lead to both lower inflation and lower output volatility. Other potential improvements may have been the relinquishing over direct price and income controls and better measurement of spare capacity.

To get a firmer grip on the sources of the greater stability, Martin and Rowthorn use a new method to decompose changes in volatility into changes in initial economic conditions, changes in economic behaviour (of both private sector and authorities) and changes in shocks. While the role of initial conditions generally is relatively small, changes in economic behaviour were the main source of the growth volatility reduction for the Euro area and Japan, while for the U.S. and the U.K. the main source were changes in shocks. Shocks are also the main driving force of lower inflation variability in the U.K. and Japan. Digging deeper, the changes in the shock components of output and inflation can be largely attributed to direct output, respectively inflation shocks. Yet, this is not the end of the story, since the obvious question then is, what causes these shocks? While, by definition, shocks are the unexplained part of a model, further empirical analysis indicates that the variances of both output and inflation shocks are increasing in the average inflation rate, thus again pointing to monetary policy as the main contributor to reducing fluctuations. Trying to look into the future, simulations show that a prolongation of the current low volatility situation requires current stable monetary policies to be continued and shocks not to increase substantially from those experienced recently.

Let us turn attention to the insights New-Keynesian economics provides for the design of monetary policy. A key lesson is that under full price stability (zero inflation), losses arising from unwarranted price dispersions (as, for example, produced by staggered Calvo (1983) contracts in an inflationary environment) are minimized. According to the New-Keynesian view, the output gap should be defined as the difference between actual output and the (time varying) output level that prevails under fully flexible wages and prices. The flexible wage/price output level (the natural rate of output) fluctuates - for example, 
owing to productivity or other supply shocks. It may be even more volatile than actual output under sticky prices. This view of the output gap contrasts sharply with the one traditionally adhered to by central bankers, who consider the output gap as the difference between actual output and some smoothed version of output (such as output following a time trend or output after the removal of the cycle using a Hodrick-Prescott filter). Predictably, central bankers would be very reluctant to target an output level that fluctuates. The obvious question then arises whether central bankers are wrong in their policies or whether New-Keynesian theorists overlook potential considerations that are relevant for central bankers in their policies. Alex Cukierman (2005) argues that the latter may well be the case. The fundamental explanation is a second-best argument, namely a pre-existing distortion (the presence of monopolistic competition) due to which the removal of nominal stickiness may actually reduce welfare. In such a case, targeting the flexible price level of output may no longer be optimal.

Cukierman illustrates his argument by comparing the outcomes under flexible and sticky wages and prices in a simple static model that features productivity shocks. Under flexibility, nominal wages and prices are set after the realization of the productivity shock, while in the other case both are set before the shock takes place. Thus, in the latter case, the real wage cannot react to the shock realization. In both cases, a negative productivity shock causes a fall in profits, which, owing to a negative income effect, leads to less leisure and, thus, an increase in the labour supply. This mitigates the negative effect of the productivity shock on economic activity. However, in the case of flexibility, there is an additional effect on the labour supply caused by a fall in the real wage. As a result, in this case leisure is less volatile, but consumption is more volatile than under stickiness. Hence, the trade off between the two cases depends on the degree of risk aversion to consumption uncertainty relative to that for leisure uncertainty. Cukierman demonstrates through an example that there exist cases in which sticky wages and prices are welfare superior to flexible wages and prices. Moreover, he derives a formal criterion for this to be the case. Translated in terms of its policy implications, Cukierman's argument provides support for central bankers to target a smoothed output level in the presence of nominal stickiness. Although the paper does not touch upon the issue of the observability of the shocks, one can speculate that the case for targeting a variable level of potential output becomes even weaker when supply shocks are only imperfectly observed and, hence, the actual level of potential output cannot be established precisely.

In his paper Jeffrey Amato assesses the problems in implementing the NewKeynesian proposals for setting the interest rate in the daily conduct of monetary policy. The task to steer the economy towards the flexible wage/price 
output level (the natural rate of output) is equivalent to the task of equalising the actual real rate of interest with the so-called "natural rate of interest." This concept, initially introduced by Knut Wicksell, and revived in the NewKeynesian approach, characterizes the real interest rate that would be realised in a flexible price rational expectations equilibrium. This suggests that actual interest policy might be framed in terms of the natural rate of interest as a key benchmark indicator for monetary policy. The fact that the natural rate cannot be observed, however, casts doubt on its practical relevance. Amato presents evidence that simple measures of the real rate gap have not been good indicators of aggregate price changes. He shows that uncertainty about the level of the long-run natural rate may have a much bigger impact on the setting of the nominal interest rate than uncertainty about the desired sensitivities of policy to inflation and output fluctuations.

In view of these uncertainties, it has been suggested that central banks should follow a rule specified solely in terms of observable variables. In some NewKeynesian model specifications, inflation turns out to be a sufficient statistic for monetary policy in which case the choice of an appropriate rule is comparatively simple. However, as Amato points out, this result is likely not to be robust to more realistic settings. First, in the presence of nominal wage stickiness, monetary policy should not only respond to price inflation (see also the contribution by Cukierman). Second, if nominal rigidities are not caused by staggered prices but are due to imperfect information, the information content of the inflation rate may be distorted. Finally, financial market imperfections (resulting, for example, in varying risk premia) may affect the link between the real rate gap and other variables in the economy. Amato argues that further research is needed about the impact of financial frictions on the natural rate and the monetary transmission mechanism.

Charles Goodhart and Boris Hofmann assess the empirical performance of the New Keynesian model. They provide an extensive survey of econometric estimations of the model and show that, up to now, empirical evidence is rather mixed. According to the theory, the key equations to be estimated (both the Phillips curve and the IS curve) should be purely forward looking (that is, they should only depend on expected future variables). But econometric estimations with hybrid specifications (also allowing - in a rather ad hoc way - for backward-looking expectations) typically result in a much better performance. Nevertheless, even the hybrid versions show significant problems with the model. There is considerable unresolved debate about the mix of forward- and backward-looking behaviour. Furthermore, the key monetary transmission parameters are often poorly identified. For example, empirical research often fails to find a significant negative effect of the real interest rate on the output gap. 
Goodhart and Hofmann argue that the poor performance is due to the omission of important variables that provide information about future output (such as the exchange rate or property and share prices), and about supply shocks (such as oil or other commodity and import prices). To fix this problem, they enrich the specification with proxies for supply shocks and for information about future output. Overall, the estimated hybrid representation of the economy turns out to offer a plausible description of the elements affecting both inflation and the business cycle. Their results suggest that a richer specification of the empirical New Keynesian model appears to be needed in order to obtain more plausible estimates of key macroeconomic relationships.

In a stimulating panel discussion at the conference, Rick van der Ploeg pointed out that even though there has been considerable progress in understanding some crucial elements of Keynesian economics, key features are still not yet modelled in a satisfactory way. This has motivated him to write a critical review of the macroeconomic debates, putting the New-Keynesian approach into a broader historical perspective. In this final paper of this conference issue, he first gives a detailed historical account of the various schools of macroeconomic thoughtstarting with classical and old-Keynesian macroeconomic theories up to the Real Business Cycle model. Then, he points out the key contributions of New Keynesian Economics from this perspective. By departing from a competitive framework, this theory captures wage and price sluggishness and aggregate demand externalities in a stochastic dynamic framework, based on explicit micro-foundations. The forward-looking nature of the model gives a key role to expectations and commitment. Policy actions today can have a strong influence on the economy when there is a credible commitment to a specific future policy path. The careful micro-foundations allow for an exact welfare analysis (with the loss function derived as a second-order approximation to a proper micro-founded utility function of the representative agent).

However, as van der Ploeg argues, these advantages come at the cost that some essential features stressed by Keynes are not captured in the New-Keynesian model. According to van der Ploeg, the main deficiencies are the inability to predict a pro-cyclical real wage in the face of demand shocks, as well as the absence of inventories, credit constraints and bankruptcies (financial frictions) in explaining the business cycle. Furthermore, labour market rationing, being a key Keynesian feature, is not captured. In reality, unemployment is experienced as a catastrophic event, with the risk concentrated among specific groups in the population. Therefore, a proper modelling and a proper welfare analysis would require heterogeneity of agents and the consideration of distributional issues. According to van der Ploeg, economists still have a long way to go before they capture the most important ideas of John Maynard Keynes and his followers. 
The contributions in this issue demonstrate the substantial progress that we have made in understanding Keynesian features: the views about stabilisation today are very different from those in the textbooks of the 1960s. Using wellstructured dynamic models and introducing real life features such as price stickiness and imperfect competition, we have made progress in understanding the economic effects of the various types of shocks, economic structures, market imperfections and institutions. Modern macroeconomics provides a sound welfare theoretical basis for analysing different policies. It shows that a deep recession causes substantial welfare losses. It also provides a new main reason for stabilising inflation - the gains from overcoming relative price distortions due to staggered prices.

Nevertheless, a number of important unresolved challenges remain. It turns out to be extremely difficult to generate models that show a similar degree of persistence as observed in the data. So far, there has been no agreement on one of the most challenging questions: what are the main sources driving business cycles? The fact that the empirical performance of the New Keynesian models is significantly improved, when additional frictions are introduced, indicates how difficult it is to model inter-temporal considerations within the current infinite-horizon framework. The model does not seem to capture unemployment adequately. Movements in labour market are modelled as movements along the individual labour supply curve. However, as a stylised fact, short-run fluctuations in activity primarily lead to variations in employment rather than changes in working hours. In reality, unemployment is mostly involuntary, while, moreover, unemployment risk tends to be concentrated among specific groups, such as the low skilled. Consequently, distributive aspects are crucial for understanding the welfare gains from stabilisation, even though such aspects are not captured in representative agent models. This suggests an additional motive for stabilising the business cycle, because such a policy may help in mitigating incentive problems inherent in social assistance programs.

The editors hope that this conference issue will convince the reader about the importance of stabilisation policy and that it will stimulate further research in this area. 


\section{References}

Amato, J. (2005), "The Role of the Natural Rate of Interest in Monetary Policy", this issue.

Andersen, T.M. (2005), "Is there a Role for an Active Fiscal Stabilization Policy?", this issue.

Ballabriga, F. and C. Martinez-Mongay (2003), "Has EMU Shifted Monetary and Fiscal policies?", in: M. Buti (ed.), Monetary and Fiscal Policies in EMU, Cambridge University Press, Cambridge, 246-272.

Beetsma, R. and H. Jensen (2004), "Mark-up Fluctuations and Fiscal Policy Stabilization in a Monetary Union", Journal of Macroeconomics 26, 357-376.

Beetsma, R. and H. Jensen (2005), "Monetary and Fiscal Policy Interactions in a Micro-founded Model of a Monetary Union", Journal of International Economics, forthcoming.

Blanchard, O.J. and R. Perotti (2002), "An Empirical Characterization of the Dynamic Effects of Changes in Government Spending and Taxes on Output", Quarterly Journal of Economics 117(4), 1329-1368.

Burnside, C., M. Eichenbaum and J.D.M. Fisher (2003), "Fiscal Shocks and their Consequences", NBER Working Paper No.9772.

Canova, F. and E. Pappa (2002), "Price Dispersions in Monetary Unions: the Role of Fiscal Shocks", CEPR Discussion Paper No.3746.

Cukierman, A. (2005), "Keynesian Economics, Monetary Policy and the Business Cycle - New and Old", this issue.

Fatas, A. and I. Mihov (2001), "Fiscal Policy and Business Cycles: An Empirical Investigation", Moneda y Credito 0(212), 167-205.

Favero, C.A. (2003), "How Do European Monetary and Fiscal Authorities Behave?", in: M. Buti (ed.), Monetary and Fiscal Policies in EMU, Cambridge University Press, Cambridge, Chapter 7.

Galí, J. (2005), “Modern Perspectives on Fiscal Stabilization Policies”, this issue.

Galí, J. and R. Perotti (2003), "Fiscal Policy and Monetary Policy Integration in Europe", Economic Policy 37, 533-572.

Giavazzi, F. and M. Pagano (1990), "Can Severe Fiscal Contractions Be Expansionary? Tales of Two Small European Countries", NBER Macroeconomics Annual 5, 75-110. 
Giuliodori, M. and R. Beetsma (2004), "What Are the Trade Spillovers from Fiscal Shocks in Europe? An Empirical Analysis", De Economist, forthcoming.

Goodhart, C. and B. Hofmann (2005), "The Phillips Curve, the IS Curve and Monetary Transmission: Evidence for the US and the Euro Area", this issue.

HM Treasury (2003), Fiscal Stabilization and EMU: A Discussion Paper, London.

Marcellino, M. (2002), "Some Stylized Facts on Non-Systematic Fiscal Policy in the Euro Area", CEPR Discussion Paper No.3635.

Martin, B. and R. Rowthorn (2005), “Accounting for Stability”, this issue.

Mountfort, A. and H. Uhlig (2002), "What Are the Effects of Fiscal Policy Shocks?”, CEPR Discussion Paper No.3338.

Muscatelli, A. and P. Tirelli (2005), "Analyzing the Interaction of Monetary and Fiscal Policy: Does Fiscal Policy Play a Valuable Role in Stabilisation?", this issue.

Perotti, R. (1999), "Fiscal Policy in Good Times and Bad", Quarterly Journal of Economics 114, 1399-1436.

Perotti, R. (2005), "Estimating the Effects of Fiscal Policy in OECD Countries", CEPR Discussion Paper No. 4842.

Ploeg, F. van der (2005), "Back to Keynes?", this issue.

Woods, R. (2005), "Fiscal Stabilisation and EMU”, this issue. 